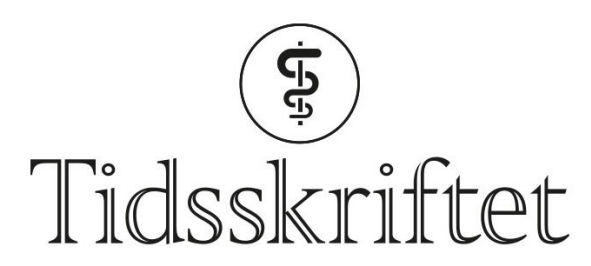

DEN NORSKE LEGEFORENING

\title{
Skamben bør kastes ut av ordbøkene
}

SPRÅKSPALTEN

ERLEND HEM

E-post: erlend.hem@medisin.uio.no

Erlend Hem (f. 1970) er fagsjef og redaktør for Tidsskriftets språkspalte.

\section{PER BRODAL}

Per Brodal (f. 1944) er professor emeritus i anatomi, med spesialkompetanse innen nevrobiologi og medisinsk utdanning.

Den delen av bekkenet som ligger fremme ved symfysen, ble tidligere kalt for skambenet. Mange synes det er et upassende ord. Så hva bør knokkelen kalles?

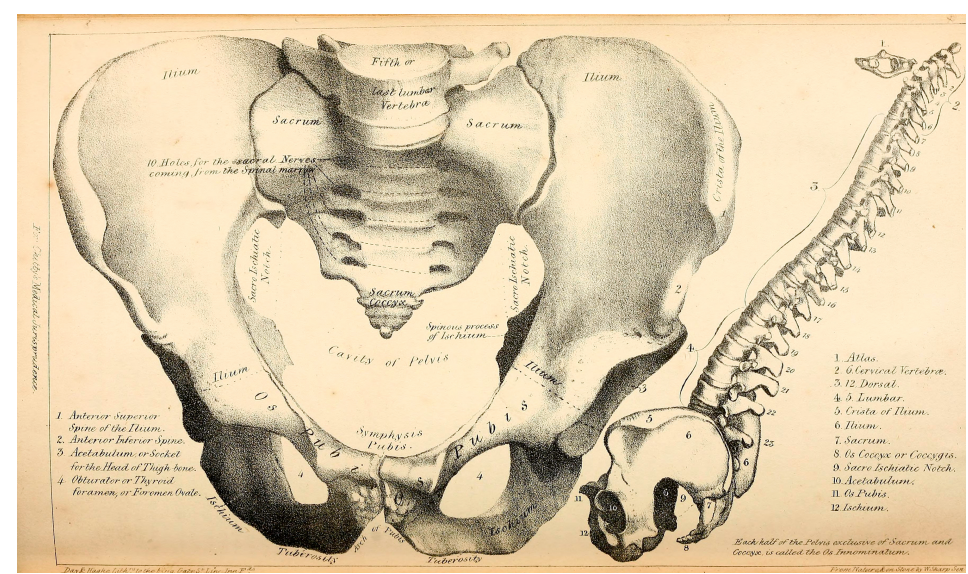

Os pubis, som tidligere ble kalt skambenet, består av to grener. Fortil, hvor greinene møtes, danner de hver sin halvdel av symfysen (symphysis pubica), som er en bruskforbindelse mellom de to bekkenhalvdelene. Illustrasjonsfoto: A Practical Treatise On Medical Jurisprudence / flickr

Tidligere snakket man om både skamlepper og skamben, men selv om skamlepper fremdeles finnes som oppslagsord i ordbøkene (1), er det så godt som helt fortrengt av kjønnslepper (2). Bra er det.

\section{Skamben}

Ordet skamben er imidlertid fortsatt i bruk. I Medisinsk ordbok står riktignok at det er en «eldre betegnelse på underlivsben» (3), men i øvrige ordbøker er skamben eneste oppslagsord (4-7).

Ordforbindelser med skam- om kroppen bør skiftes ut. Det fantes faktisk flere av dem. Skamleppene er alt nevnt, andre eksempler som fremdeles finnes i ordbøkene er skamsprekk eller skamspalte om «mellomrommet mellom kvinnens skamlepper» (4), skambensbuen, skambenskammen (4) og skambenfugen (3). Til og med skamhår er 
registrert, med forklaringen kjønnshår (7).

\section{Underlivsben}

I en lærebok i anatomi fra 1919 foreslo legene Kristian Emil Schreiner (1874-1957) og Alette Schreiner (1873-1951) å bruke underlivsben for skamben: «Istedenfor det lite tiltalende navn "skambenet» (tysk Schambein) (...) har vi brukt betegnelsen underlivsben», skrev de (8). Dette er første gang ordet «underlivsben» dukker opp i det digitale nasjonalbiblioteket (bokhylla.no), så antagelig er vi her ved opphavet. I senere utgaver brukte de kun «underlivsben»-skamben nevnes ikke. Dagens anatomibok bruker også betegnelsen underlivsben (9), sikkert fordi den er en videreføring av Schreiner \& Schreiners bøker, læreverk som var toneangivende for norsk anatomisk nomenklatur i generasjoner.

Ekteparet Schreiners initiativ fra 1919 er interessant. De ønsket å fornorske flere ord i den menneskelige anatomi. Å finne gode norske navn for de forskjellige deler av skjelettet og for de enkelte muskler var ingen lett sak, skrev de. De bygde på lærebøkene til forgjengeren Gustav Guldberg (1854-1908), men var ikke fornøyd - «resultatet av vort arbeide ennu langt fra tilfredsstiller os». I forordet nevnte de tre nye betegnelser som de hadde laget: ribbe for ribben, ristben for rulleben og underlivsben for skamben (8).

Vi har forhørt oss blant kolleger, som sier at skamben er forlatt i fagkretser for lenge siden. De synes det er pussig at ordboksforfattere ikke har fått det med seg. Andre foretrekker å snakke om «symfysen», da unngår man hele problemet med «skamben». Men symfysen er bare en omtrentlig stedsangivelse, og noe annet enn os pubis, selv om de henger sammen. Ordet skamben er nok lite brukt i medisinen i dag. I Tidsskriftets nettutgave, som omfatter alt stoff fra 2000, er faktisk verken skamben eller underlivsben nevnt - os pubis er brukt tre ganger.

\section{Kjønnsben}

Et alternativ til underlivsben er «kjønnsben». Det gir en del treff i både dansk (10) og norsk. Logisk er det også. Kjønnsben er analogt med kjønnslepper. Dessuten er det språklig fornuftig, ettersom det latinske pubes betyr kjønnshår og os pubis burde vel derfor kunne kalles kjønnsben. Kjønnsben har en litt kortere historie enn underlivsben. Første treff i bokhylla.no er i en lærebok i fødselshjelp fra 1959 (11).

Språkrådet har tilrådet underlivsben på grunnlag av Medisinsk ordbok og Norsk ordbok (Kunnskapsforlaget) samt at ordet har vært lenge i bruk i fagbøker. Etter vår mening er kjønnsben et godt alternativ. Det skaper en logisk sammenheng til kjønnslepper og er vel mer beskrivende enn underlivsben. Hvis man skulle begynne på nytt i dag med navngivning, ville nok kjønnsben være å foretrekke.

\section{LITTERATUR:}

1. Skamleppe. I: Bokmålsordboka og Nynorskordboka. http://ordbok.uib.no/perl/ordbok.cgi?OPPskamleppe (9.10.2017).

2. Skamlepper, kjønnslepper. NB N-gram beta. Nasjonalbiblioteket. www.nb.no/sp_tjenester/beta/ngram_1/\#ngram/query?termsskamlepper\%2C+kj\%C3\%B8nnslepper\&langall\&case_sens=o\&freqrel\&corpusbok (9.10.2017).

3. Skamben. I: Nylenna M. Medisinsk ordbok. www.ordnett.no/search?languageno\&phraseskamben (9.10.2017).

4. Lindskog BI. Gyldendals store medisinske ordbok. 2. utg. Oslo: Gyldendal, 2003: 504.

5. Øyri A. Norsk medisinsk ordbok. 9. utg. Oslo: Det Norske Samlaget, 2011: 984.

6. Skambein. I: Bokmålsordboka og Nynorskordboka. http://ordbok.uib.no/perl/ordbok.cgi?OPPskambein (9.10.2017). 
7. Kirkeby P-E. Den store norske bokmålsordboka. Oslo: Kagge, 2014:1417.

8. Forord. I: Schreiner KE, Schreiner A. Menneskeorganismen: lærebok for studerende og lærere. Del 2. Skjelett-muskelsystemet. Kristiania: Steenske forlag, 1919: IV.

www.nb.no/nbsok/nb/c9a4fd56cbee6dbe2oeofo86bb7546bf.nbdigital?langno\#7 (9.10.2017).

9. Dahl HA, Rinvik E. Menneskets funksjonelle anatomi: med hovedvekt på bevegelsesapparatet. 3. utg. Oslo: Cappelen akademisk, 2010: 452.

10. Skamben. I: Dansk Wikipedia. https://da.wikipedia.org/wiki/Skamben (9.10.2017).

11. Løvset J, Brandstrup E. Lærebok i obstetrikk for jordmødre. Oslo: Aschehoug, 1959: 11.

www.nb.no/nbsok/nb/b7f2f18ccc737d7cf9cad67d50degeac.nbdigital?langno\#10 (9.10.2017).

Publisert: 12. desember 2017. Tidsskr Nor Legeforen. DOI:10.4045/tidsskr.17.0914

(C) Tidsskrift for Den norske legeforening 2020. Lastet ned fra tidsskriftet.no 